\title{
Importance Of The Segmentation On Time-Rich And Time-Poor For Development And Marketing Of Computer Games
}

Helena Lindskog (Email: helli@eik.liu.se), University of Linköping, Sweden Rasmus Larsson (Email: rasmus@ rasmus.se), Rasmus Larsson AB, Sweden

\begin{abstract}
ICT (Information Communication Technology) development has already changed many aspects of our life. One of the most successful industries in using ICT as a means for development of new products as well as marketing and sales activities, is the entertainment industry. The games industry is developing rapidly and has penetrated every layer of society. In 1998 video and electronic game revenues reached
\end{abstract}

USD 5.5bn in North American markets alone. The annual increase has been approximately $25 \%$ during a number of years.

The success of ICT based entertainment products depends to a high degree on the penetration of PCs and Internet connections. Many governments all over the world have strategies and programs in order to reduce the digital divide and to offer all citizens Internet access. In the not so distant future Internet access will be as natural as water, electricity, radio or telephone.

Time is more and more becoming an important variable for market segmentation. Everybody has 24 hours per day and night at his or her disposal. However, the perception of time varies. Some feel they have too much time and they are time-rich. Some feel that they have too little time and they are time-poor.

Traditionally, time-rich people were also money-rich, but the big majority was both time-poor and money-poor. This is completely turned upside down in the Information society. Nowadays people are equally divided between time-rich and money-poor, and time-poor and money-rich. Both timerich and time-poor need entertainment and are potential consumers of entertainment especially games as e-services but in different ways.

This is a conceptual paper and its purpose is to investigate the importance of the division on timerich and time-poor for the entertainment industry and practical implications with a special focus on computer games as products and e-services.

Readers with comments or questions are encouraged to contact the authors via email. 


\subsection{Background}

The Information society opens up for new possibilities and for new challenges. The information Communication Technology (ICT) enables new ways to work, to buy products and services, to contact government and to be in touch with friends and family as well as to spending your leisure time.

Several initiatives have been taken in most of the countries in the world in order to reduce the digital divide between the initiated and those who do not have access to the world of Internet, WorldWideWeb, PCs, SMS, WAP etc. The technical development of new man-machine interfaces, new devices and the use of Internet-like applications in existing equipment such as TV sets and telephones contribute to improve the accessibility, as do the use of broadband techniques to enterprises, governments and households. More and more people use Internet in their work and also after working hours. We are in a transitional period when all effort is concentrated on achieving the goal of having the same natural access to Internet as to water, electricity, TV, transportation or telephone.

To reduce the digital divide has top-priority. "One of the most important goals for the European governments is to reduce the digital divide that exists in the society." (Jose Dias Coelho, 2001). One of several European projects is An Information Society for All. "The initiative has a number of key objectives; first being to bring everyone - citizen, home and school, every business and administration - into the digital age. A second aim is to create a digitally literate Europe, supported by an entrepreneurial culture, ready to finance and develop new ideas; and third, to ensure the whole process is socially inclusive, building consumer trust and strengthening social cohesion." (European Commission, 2000)

Even so that games and gaming are as old as the humanity and a game concept has existed in all types of society, it is still so that development of the ICT means a completely new era for this old activity. Internet, broadband and mobility give many new, never before existing possibilities and business opportunities.

\subsection{Time-Rich and Time-Poor}

In affluent societies where services, products and possibilities abound, time is an important parameter. While each day still has 24 hours for everyone, the perception of time varies. Time-rich people feel they have enough or too much time while time-poor people feel time is a major constraint in their daily life. This difference in the perception of time is important to take into account in development of marketing strategy and to be included in any analysis of market segmentation, the development of products and services and the choice of market channels (cf. Kotler and Armstrong, 1997).

Already in the 1960s, the Swedish economist Staffan Burenstam-Linder pointed out in his book "The Hurried Leisure Class" that consumption in an affluent society is limited by our scarcest resource: time. He showed that the mechanism behind time-poverty depends on the increasing amount of products in the market. His predictions such as increasing prosperity is not giving us "... peace and harmony... in reality it is in this case in contrary. The pace increases and life becomes more hectic." (Burenstam-Linder, 1969) are now becoming evident. The amount of products and services increases dramatically and continues to do so. His words "...not only production but also consumption demands time" are valid today and in the future.

More recently Paul Romer, professor of economics at Stanford University explained: "The decline in the cost of IT hardware has been so rapid that it's tempting to assume it explains all the changes that take place in the economy and society. But in our lifetime, we've witnessed a second price change that's as jolting as the one in hardware: The cost of time has increased. To be sure, the rate of increase in the cost of time has been much less dramatic than the rate of price declines in IT. But human time is used in every productive process and every consumption activity, so changes in the cost of time have pervasive effects on the economy and society." (Romer, 2000) 


\subsection{Time-Rich Market Segments}

The time-rich are people/consumers with the perception that time abounds and often associates with "killing time". This group is large, larger than in any other period of human history. However, only a fraction of the time-rich is also money-rich. This group contains the following socio-economic segments:

- $\quad$ Retired people

- $\quad$ Children and youth

- $\quad$ Unemployed

The main reasons for having such a large group of time-rich are:

- $\quad$ Retirement with pension

- $\quad$ Longer life

- $\quad$ No child labour

- Increased prosperity

To be retired with a pension is a new idea in a historical perspective. The number of retired people with pension is increasing rapidly. Life expectancy is also constantly increasing. In all this is an increasingly interesting segment from a commercial perspective.

In most countries, the law forbids child labour and the work debut is for every year becoming later. Many young people study and many are postponing their family and work responsibilities much longer than just a generation ago.

Many people fluctuate between time-rich and time-poor depending on the state of the economy. This group consists of the unemployed.

\subsection{Time-Poor Market Segments}

Most professionals and parents with small children are time-poor. Many of the time-poor perceive time as their scarcest resource and the term "saving time" is often associated with time-poor. The main reasons for having such a large group of time-poor are:

- $\quad$ Those employed have to work hard freely or as a consequence of organizational pressure

Time-poverty is associated with economic success. Work identity is for many becoming more and more important. In addition, work itself has become more exciting. It gives new challenges every day and a big dose of satisfaction. Many begin to value everything from the benefits they can get in their work-life or job career. Anthropologist Jan English-Lueck, puts it this way: "We call it techno-optimism. There is an addiction to opportunity and if you don't see it that way, why are you even here?" (Newman, 2001) Although the time-rich group is equally large, most of the interest in media is devoted to the time-poor.

- $\quad$ The distinction between work and leisure is becoming more blurred

The information technology and telecommunications give us all the possibility to work and get in touch with the office anywhere, anytime and soon even anyway. Only a few people can avoid the temptation to check the voice and e-mail messages when they are out of their office if they have the possibility to do that.

- $\quad$ The increasing supply of goods, services and choices to fill up our time

We have never before had so many choices of goods, services and activities and we must constantly take decisions at home, at work and other places. An independent job gives more degrees of freedom. Internet, TV, radio, books, games, children, parents, friends, movies, sports or shopping compete for your time and each of these activities have almost unlimited amount of choices. "Promulgators of the 24-hour society begin by identifying (correctly) two themes of modern life; first a consumerist hunger designed to be unappeasable, and second a time-sickness at the heart of an over-hurried society; too much to do, too little time." (Griffiths, May 2000) 
- $\quad$ The need to always be prepared for changes, to learn and acquire new knowledge

The technical development goes very fast and speed is likely to accelerate. Today's knowledge in many fields will be obsolete tomorrow. Life-long learning is not only a buzzword. It is in all professions becoming a reality.

- $\quad$ The consciousness that you yourself are in charge and responsible for your future

Your decisions can change your situation. It is important to meet the right people and to have the right education, be slim and tanned, wear the right cloth, read the right magazines and have the right new ideas in time that can be keys for success in the professional and social life. Many preach Carpe Diem. However, it might be difficult to combine with the responsibility for your own future.

\subsection{Time and Money - a Historical Perspective}

The antagonism between the money-rich and the money-poor has to a large extent shaped our economic and political development.

To be rich has in different eras been expressed in various forms such as the possession of land, slaves, forest, mines, precious metals, machines or buildings, to have the right position in the administrative apparatus or today by knowledge.

FIGURE 1. Time and Money in a Historical Perspective (Helena Lindskog, 2001)
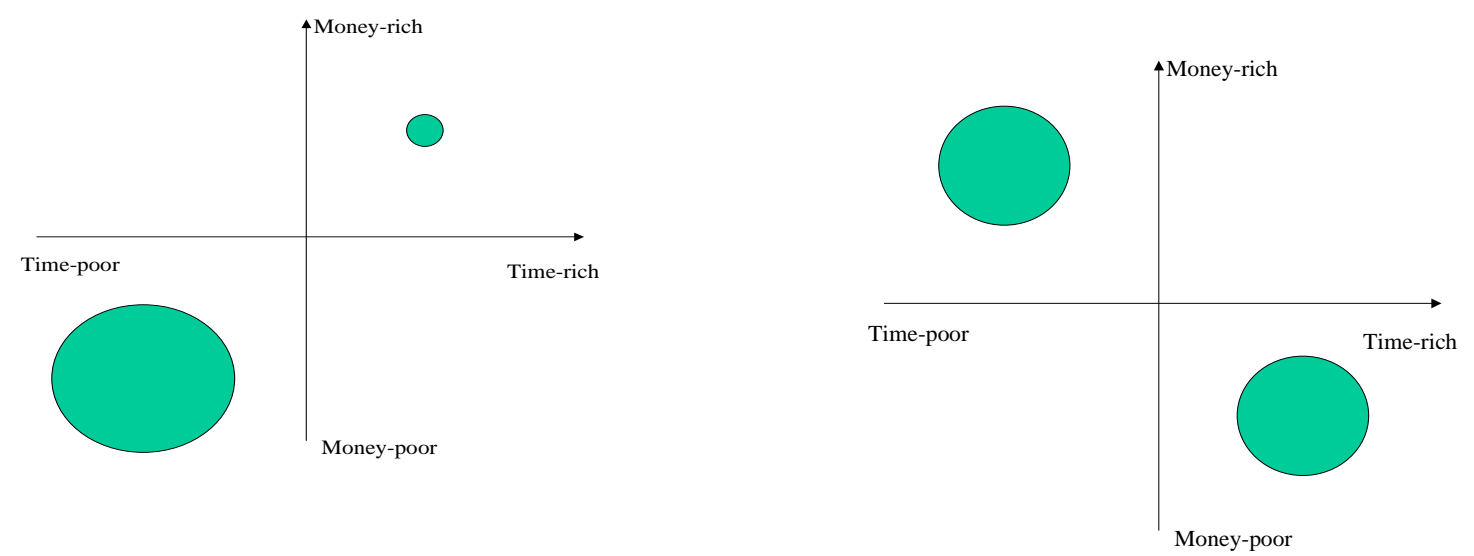

Historically, two groups have dominated. The minority was time-rich/money-rich and had power. The majority was time-poor/money-poor and without power.

The minority group time-rich/money-rich represented power and money but also culture, fashion and trendsetting. They accounted for the largest part of consumption of products, services and entertainment.

The vast majority of the population was time-poor/money-poor. All members of the family had to contribute to family survival. The possibilities to change one's situation were limited. People used most of their time to produce for others and themselves. They had no time or money to consume more than the essentials. 
Time-rich/money-poor were few. It was simply difficult to survive in this group. If somebody became sick or lost his job it easily became a catastrophe for the person himself and his whole family. In the end it could lead to famine and death.

Today, the picture is completely turned upside down. The two most dominant groups are time-poor/money-rich and time-rich/money-poor. These two groups are more or less of the same size in the developed countries.

Today's elite is time-poor/money-rich. This group is the trendsetter. People on higher positions with big salaries work more. To get to the top means more working hours, less contact with the family and old friends. Ross Gittens points out: “ ... the people pulling in those big salaries are, as a general rule, working much longer hours than people in less-paid jobs. Consider the official figures for the hours worked in August by men with full-time jobs. Almost $60 \%$ managers and $40 \%$ professionals and associated professionals worked more than 48 hours a week. By contrast, only $25 \%$ of tradesmen and $18 \%$ of laborers worked that long." (Gittens, 2000)

The time-rich/money-poor of today in most developed countries would not have been considered poor in the past. In this group we find many retired people with limited pensions, unemployed and many young people. This group is often marginalized.

\subsection{Development of Broadband Access and Mobile Communication}

All these efforts point towards reduction of the digital divide in the affluent societies. We are in the middle of a transitory stage that began with the introduction of Internet and ends with the full access to Internet for all citizens. Recent research shows (Jupiter Media Metrix) that:

- Over 33 million British people, or 60 percent of the population, used the Internet between April and June 2001

- $61 \%$ go online at home, and $32 \%$ at work. A further $32 \%$ go online at Internet cafes, libraries, friends' houses, or schools.

- $\quad 10.4 \%$ go online with a mobile phone, $1.6 \%$ with a PDA, $4.3 \%$ use interactive $\mathrm{TV}$, and $9.3 \%$ go online using a games console or other device.

Figure 2. Type of on-Line Access to Internet in the UK Q2 2001

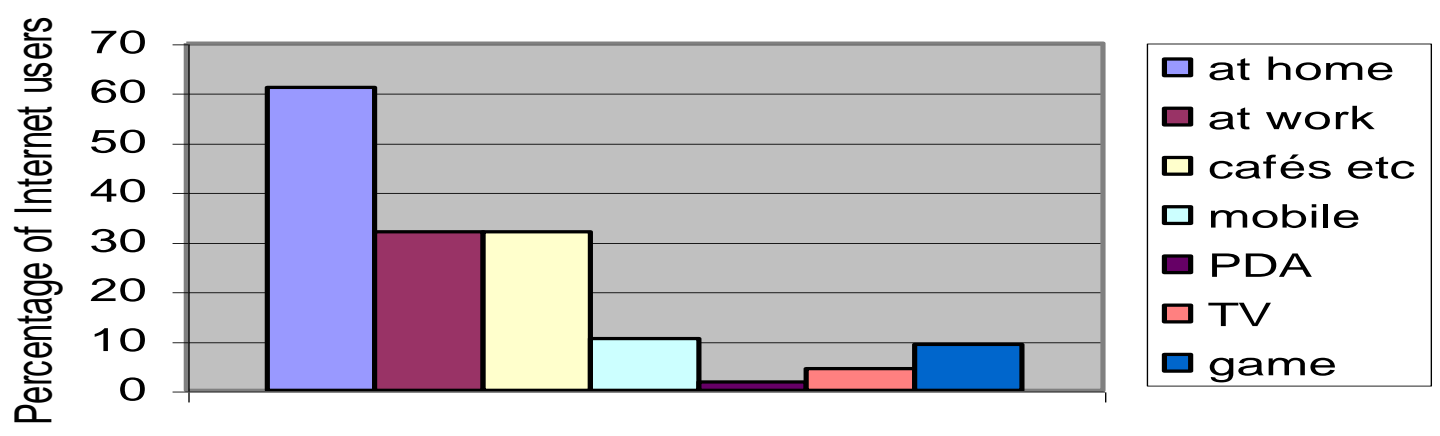

- $\quad$ The number of Internet users going on-line from home increased by approximately $260 \%$ in less than two years (from 7.8 million users in October 1999 to 20.1 million in June 2001). 
FIGURE 3. The Number of Home Internet Users in the UK

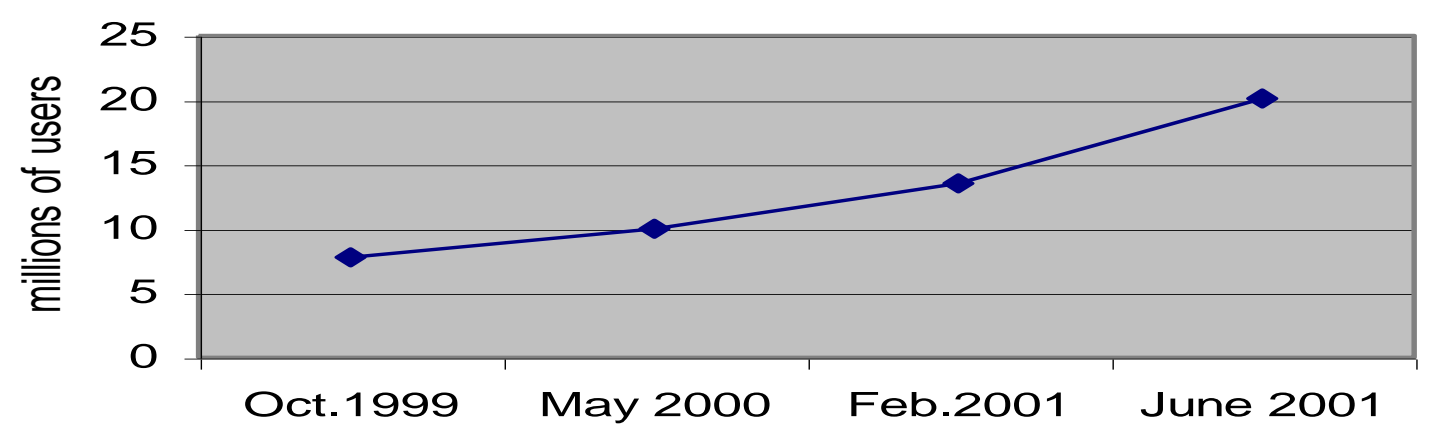

- $\quad$ "For the first time, women constituted 50\% of the online population, matching men who had dominated Internet use since Jupiter MMXI started reporting in October 1999. The same trend had occurred in the US only three months earlier." (Jupiter MMXI online Market Landspace Q2 2001).

- A similar investigation made by Jupiter MMXI in Sweden shows that the number of Swedes connected to Internet at least once a day during October 2001 was $63,6 \%$ of the population between ages 12-79. The number women connected to Internet was $47,2 \%$.

FIGURE 5. Age Distribution of Internet Users in the UK and Sweden
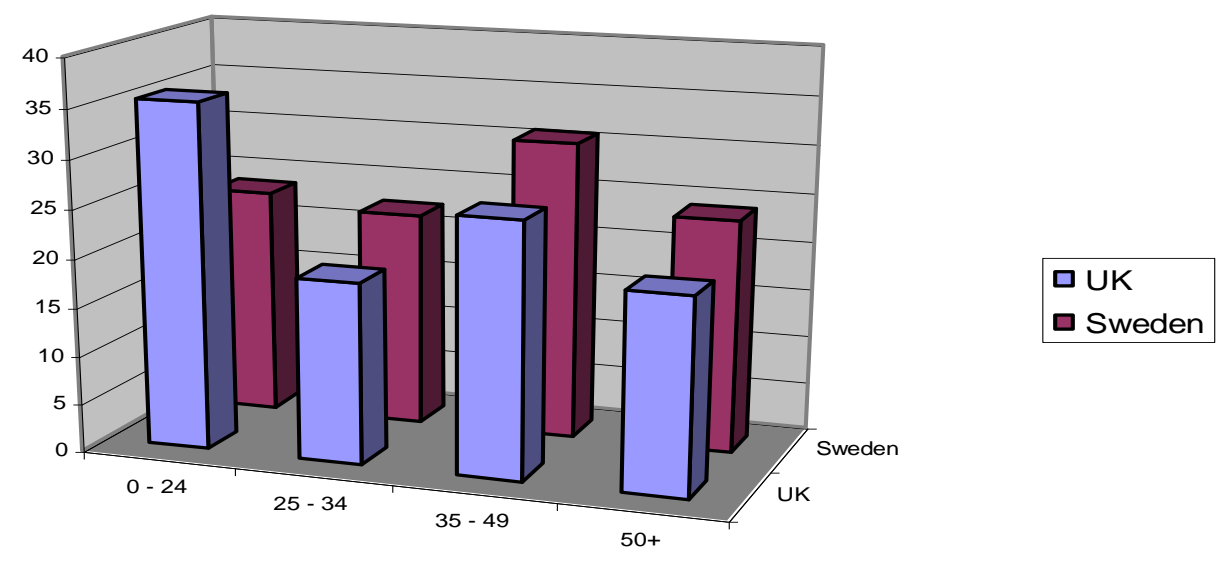

Mari Kim Coleman, Senior Vice President of Measurement concluded: "For the first time, we can see the real penetration of the Internet in the UK. No longer the preserve of the few, it clearly appeals to a broad spectrum of people - old and young, male and female, rich and poor." (Jupiter MMXI online Market Landspace Q2 2001)

The investigations carried out in the UK and Sweden underline the rapid change from few exclusive users of Internet to access to Internet for all independently of age, sex or income. 


\subsection{Primary Lines of Development for Internet User Experience}

From a product development point of view the actual technical development of the Internet is less interesting than the users experience of the technology. Currently there is an ongoing technical development of the Internet access forms that is fundamentally changing the user experience of the Internet. This opens up new opportunities for innovative e-services.

In the present situation the majority of Internet users access Internet through the dial-up PSTN (Public Switched Telephone Network) connection. The share of mobile Internet connection as well as broadband fixed access increases continuously. To understand how the user experience changes we investigate and compare dial-up, mobile and broadband Internet connections from some of the most important aspects of this experience.

Such as:

- $\quad$ Presentation as defined by users relative experience of the accessing terminal equipment's capability to offer rich media experiences.

- $\quad$ Bandwidth as defined by users relative experience of data transmission capacity.

- $\quad$ Accessibility as defined by users potential choice to use Internet in Time and Space.

- $\quad$ Presence as defined by the technological infrastructure that is already in operation or currently in planning to be built in a few years time.

In order to make this analysis possible we have assumed that infrastructure in planning will be built with similar technical characteristics as already commercially operational and successful next generation infrastructure, like I-mode or DSL-type broadband access.

TABLE 1 Characteristics of Dial-Up, Mobile and Stationary/Semi-Stationary Broadband Internet

\begin{tabular}{|c|c|c|c|}
\hline & Dial-up Internet & $\begin{array}{l}\text { User in a mobile state } \\
\text { (mobile Internet) }\end{array}$ & $\begin{array}{l}\text { User is in stationary or semi-stationary } \\
\text { state (stationary broadband) }\end{array}$ \\
\hline $\begin{array}{l}\text { Presentation } \\
\text { Bandwidth } \\
\text { Availability } \\
\text { Presence }\end{array}$ & $\begin{array}{l}\text { quite limited (low bandwidth restrain) } \\
\text { very limited } \\
\text { limited in space } \\
\text { temporarily on demand }\end{array}$ & $\begin{array}{l}\text { limited } \\
\text { limited } \\
\text { extremely high } \\
\text { continuously }\end{array}$ & $\begin{array}{l}\text { powerful } \\
\text { high on demand } \\
\text { limited in space } \\
\text { continuously }\end{array}$ \\
\hline
\end{tabular}

The table above shows clearly how dial-up, mobile and stationary/semi-stationary broadband user experiences differ radically. The dial-up Internet is limited in all aspects while mobile and stationary/semi-stationary complement each other. It means that if one aspect is weak for the stationary access, it is then strong for the mobile access. At the same time the presence aspect has the same quality for both mobile and stationary accesses but is fundamentally different from today's dial-up connections.

Today and in the near future there will be two concurrent and complimentary forms of access. Thus the debate about either mobile or stationary broadband access should be more on in which situations that should mobile or broadband connection instead of promoting one or other form of access.

In a few more years the broadband (2Mbit or more) will be combined with mobility and the situation will then be different. See table below. 
TABLE 2 Characteristics of Broadband Mobile Internet

\begin{tabular}{l|l} 
& Broadband Mobile Internet \\
\hline presentation & powerful \\
bandwidth & high \\
availability & high \\
presence & continuously
\end{tabular}

The limitations in usage will be more due to human body's functions and human behavior than technique. It is possible for us to use all the facilities and possibilities whole we move together with the terminal in the transportation object such as train, plane or bus but it can virtually impossible to watch a screen or write at the same time while running, cycling, skiing or swimming.

\subsection{Consequences}

The resulting situation is natural and desirable both for the user and for the provider of the service that can offer concurrent and complimentary services in a portfolio of these different forms of access. This way the mobile and stationary broadband service will form a whole with much higher value for the user. And as a consequence an eservice that takes advantage of this situation can provide a much higher value for the customer than a service that is only delivered using one of the access forms.

\section{Game Industry}

Games are mostly considered as leisure, pass-time activities but games have been used in many situations and for different purposes. Today the other purposes can be such as education, marketing or personal development. Gaming's role in the future will take place and have a market outside the entertainment business... ...plays and games are important phenomena and they deserve a better reputation than a pastime activity for children and youngsters. There are prejudices against gaming considering it not serious" or unnecessary pastime. But an understanding how this activity can be used by people of any age and for other purposes can result in a big market and broad usage. (Anders Frank, Spelandets roll i framtiden, September 2000)

\subsection{Computer Games as On-Line Services}

Online games are an emerging market with many opportunities and challenges for game developers. While developers have expertise in designing and developing game experiences, they require additional knowledge about the business and technology implications of online games in order to maximize their chances for success in a growing and evolving marketplace. (http://www.igda.org/Endeavors/Research/Online/online.htm)

Today's PDAs and cell phones have more similarities to PCs than ever: color screens, fast processors, and more memory for storing and displaying images. And the games you can play are improving as well. Plus, when you add Internet access (just a call away with a cell phone, but also increasingly available with PDAs), web browsers, e-mail, and instant messaging-suddenly you have wireless networks making it a snap to download a game or join in with others for multiplayer action. In fact, wireless gaming in the United States is becoming so popular that a recent report from Datamonitor Research projects it will grow into a \$6 billion market worldwide by 2005 , with four out of five mobile phone users playing wireless games. (12/06/2001, Gaming Gifts on the Go, Marshal M. Rosenthal)

\subsection{Computer Games and Segmentation Based on Time}

\subsection{Consumer Behaviors and Priorities Based on Time}

To predict consumer behaviour is tricky because there are so many factors of cultural and psychological importance that influence specific individual consumer actions. But for the sake of reasoning we will assume that a 
statistical group of consumers will tend to make rational decisions based on important priorities in their current life situation. Such an important priority could be perceived scarcity of a particular resource, like time or money.

If we look closer at our consumer segments time-rich, money-poor and time-poor, money-rich it becomes clear that they have fundamentally different priorities and therefore will be attracted by different value-propositions. The time-rich, money-poor will be attracted to propositions of time-consuming experiences for less money. Soap operas on TV are a very typical example of a product tailor made for this group. It consumes enormous amounts of time and its free or rather its not free but as a consumer you don't pay with money but with time when you watch commercials. On the other hand the time-poor, money-rich will be attracted by propositions of high quality and rich experiences with a low expenditure of time and will often gladly pay more for this.

\subsection{Computer Games}

As most things in the post-industrial era, computer games can be either commercialised as products or services or a combination of both. To get an understanding of what this means for computer games we can make the following rough definitions of the concepts of products and services.

- With product we mean a packaged, self-contained experience or object for unlimited use.

- With service we mean an on-demand or real-time produced experience which use is limited by time and/or resource expenditure.

These definitions are obviously not sufficient or correct for all types of products and services but they are good enough for our purpose of analysing computer games relative our proposed market segments. Some of the more important aspects of computer games as products respective services can be seen in table 3 .

TABLE 3 Computer Games as Products and Services

\begin{tabular}{l|l}
\hline \multicolumn{1}{c}{ As Products } & \multicolumn{1}{c}{ Computer games } \\
\hline Shrink-wrapped boxes, sold in a store & $\begin{array}{l}\text { Monthly fee for online network gaming or pay per minute } \\
\text { for cellular network-games } \\
\text { Can be solo-play, multiplayer and/or network oriented } \\
\text { Sold over the internet or in internet cafés } \\
\text { The game-application is sometimes free for download and s } \\
\text { sometimes sold as a product in stores }\end{array}$ \\
&
\end{tabular}

To further analyse this, we have tried to create an inventory of competitive features for computer games as both products and services for our respective consumer segment.

Currently most of computer games offered on the market as well as supportive business like computer games magazines and computer games stores shows that the whole industry aims towards a consumer segment that demands lots of experience time for a small amount of money. This is confirmed when speaking to people currently working in the industry where "truths" about the consumer market are typically expressed like "A game has to have at least a 100 hours of playing time to sell at all today, two years ago it was sufficient with 30 hours." (from interview with Robert B. computer games designer, 2001) or "Our customers have a small and fixed amount of money each month to spend on entertainment. We compete with both the music industry and the film industry about as large a share of this amount as possible each month. If we lower our prices they won't buy a second game, they will go somewhere else and buy a bloody record for that money" (stated by game storeowner in discussion with employees about pricing, 1991). 
TABLE 4 Competitive Features for Computer Games as Products

Competitive Features for Computer Games as Products

\begin{tabular}{l|l}
\hline \multicolumn{1}{c|}{ For Time-Poor, Money-Rich } & \multicolumn{1}{c}{ For Time-Rich, Money-Poor } \\
\hline $\begin{array}{l}\text { No threshold. The gaming experience must start at once. } \\
\text { No intro sequence. }\end{array}$ & $\begin{array}{l}\text { A long playing time. Currently boxed games are sold with a } \\
\text { minimum playing time of } 100 \text { hours. } \\
\text { Long mood-setting intro films. } \\
\text { No set-up time. }\end{array}$ \\
$\begin{array}{l}\text { Intense experience. } \\
\text { Rixed playing time. "Hey, lets take a break and play a } 15\end{array}$ & $\begin{array}{l}\text { Addictiveness based on continued and escalating experience. } \\
\text { "I just have to check the next level, do this last task, talk to } \\
\text { minutes Quake session!" }\end{array}$ \\
$\begin{array}{l}\text { Guaranteed sense of fulfilment after each fixed-time game } \\
\text { session. } \\
\begin{array}{l}\text { Addictiveness based on repeat experience of similar quality. } \\
\text { "I need a quick fix to be able to work for another hour." }\end{array}\end{array}$ & $\begin{array}{l}\text { Fixed cost for unlimited use. } \\
\text { A working second hand market. }\end{array}$
\end{tabular}

TABLE 5 Competitive features for computer games as services

Competitive Features for Computer Games as Services

\begin{tabular}{|c|c|}
\hline For Time-Poor, Money-Rich & For Time-Rich, Money-Poor \\
\hline No threshold. The gaming experience must start at once. & $\begin{array}{l}\text { complex playing experience with a sense of } \\
\text { otential. }\end{array}$ \\
\hline od & $\begin{array}{l}\text { Character developing by in-game experience over a long- } \\
\text { playing time. }\end{array}$ \\
\hline & eal-time experience in an immerse-media setting. \\
\hline $\begin{array}{l}\text { Intense experience for a short } \\
\text { intense experience in the }\end{array}$ & hange or expand the \\
\hline s when & based \\
\hline ry & $\begin{array}{l}\text { ss based on continued and escalating experience. } \\
\text { to check the next level, do this last task, talk to } \\
\text { an that strategy..." }\end{array}$ \\
\hline d sense of fulfilment after each fixe & Fix \\
\hline ddictiveness bas & games \\
\hline
\end{tabular}

The above tables show clearly that there are big differences between competitive features in these consumer segments. Sometimes they are even mutually exclusive. Time-poor don't want intros and they hate setuptime. Time-rich like long intros and want to co-create by changing and editing everything before play-start.

An interesting question is what happens if you mix features wrong? A stunning example of this is a game as service that was offered to consumers by a Swedish mobile-phone operator during 2001. The game was attractive for kids and based on a continued and escalating experience. Thus it offered a value proposition for time-rich, money-poor. But at the same time they charged for it as a service with payment based on actual use per minute. This is typically a payment model attractive to time-poor, money-rich. After a couple of weeks they had to shut down the service due to a highly aggressive media-campaign launched by parents who had no intention of paying the huge phone-bills their kids had accumulated. 
The results seen in the two tables above show an inventory of competitive features for computer games for time-rich, money-poor and time-poor, money-rich. These results are based on interviews at computer games shops and with computer games developers, observations and own experiences as well as from computer game related press. It was much easier to obtain information about time-rich money-poor-group than on time-poor, money-rich group and thus too create an inventory for time-poor, money-rich was much more difficult.

An example of already existing studies of games for time-poor is development at MIT placed in Dublin, Irland. Most video games tend to get the pulse racing, but researchers in Dublin, are working on developing games to help calm people.

One of games is the two-player dragon racing game called Relax To Win. The idea is simple. Two electrodes are attached to a player's fingers and as the person relaxes, their dragon moves faster. The game uses galvanic skin response technology, which works measuring the ability of the skin to conduct electricity. This changes as a person relaxes or tenses up and forms the basis for lie detector tests. "As you relax, your dragon will walk, then run and then fly," Dr McDarby said. "If you can get it to fly, it means you have got into a nice relaxed state. "The technology is trying to make decisions to improve or enhance your state of mind," he explained. The game takes place in a virtual 3D-world set aboard a starship in space. The environment is designed to immerse the player, drawing more of their attention and making the feedback more effective. "We're looking at a medium that a lot of people are drawn to and how we can use this constructively," he said. (Alfred Hermida, BBC News Online technology staff, Wednesday, 8 May, 2002, 09:30 GMT 10:30 UK, Video games to help you relax, The faster you relax, the faster you go)

\subsection{Economical Potential in Game Services for Time-Poor}

Sales of computer games for pre-school children have risen by 40 per cent in the past 12 months. The preschool market is now the fastest growing sector of the computer games industry, which grew as a whole by six per cent in the past year. (Tuesday, 17 April, 2001, 12:43)

Sales of computer games hit a record year in 2001 with more than 1.6 billion GBP, the European Leisure Publishers Association (Elspa) said. It also found that demand for software and consoles increased by $36 \%$ on the previous year. Most investments go into development of games for the time-rich group that wants to get as much value for as long time as possible. It means that new games are longer and more complex so that you can for the same amount of money use it without repetition for longer time. This approach disregards the needs of time-poor where the majority of wealthy people are.

As has been shown above the time-poor wants intense but fixed-time and short gaming experiences. This can easily be translated into low production costs. At the same time they have the ability to pay more and will do so for a higher quality of experience. This points towards the opportunity to create a new and highly lucrative gaming industry aimed at the time-poor, money-rich.

\subsection{Conclusions}

There is an ongoing discussion on market segmentation based on age and sex. However, to segment the market on time-rich and time-poor looks much more relevant considering the nature of any e-services. This segmentation better captures the purpose of gaming and the preferences of each group. The time-poor are mostly wealthier than the time-rich but games today typically aim at the time-rich. The gaming needs and economical potential of time-poor are not considered and only addressed indirectly (by addressing children to time-poor and rich people). This paper discusses characteristics, needs and the possibilities for development of games as e-services especially for time-poor. 


\section{References}

1. Helena Lindskog - Tidrika och tidfattiga - de nya samhällsklasserna, HelDag, May 2002

2. Robert Verrue, DG Information Society Director-General - European Commission response to the "Digital Divide" challenge, The United Nations Newsletter, November 2000

3. $\quad$ Kotler and Armstrong - "Marketing - an Introduction", Prentice Hall, London, 1997

4. Staffan Burenstam-Linder - Den rastlösa välfärdsmänniskan, Tidsbrist i överflöd - en ekonomisk studie, 1969

5. Paul Romer - Time: It Really is Money, Information Week, September 2000

6. Newman Cathy - Silicon Valley Incubator, National Geographic, December 2001

7. Jay Griffiths - Colonising the night, Red Pepper, May 2000

8. Ross Gittens - It's true, time is money (tax-free), The Age, Australia, October, 2000

9. Michael Bittman - Social Participation and Family Welfare: The money and time costs of leisure, Social Policy Research Centre, University of New South Wales, November 1998

10. Jupiter MMXI on line Market Landscape Q2 2001

11. Gene Epstein- Barron, November 1999

12. Helena Lindskog - Marknadssegmentering, January 2000

13. Helena Lindskog - Time-rich and Time-poor, A New Way For Market Segmentation, 2001

14. BetterTimes newsletter - Strain drain, Time Poverty and Bad Sex in Cool Britannia, September 1999

15. Jupiter MMXI Sverige - Den surfande befolkningen, November 2001

16. Jupiter MMXI UK-60\% of Britons now using the Internet, July 2001

17. Anders Wijkman - Bridge the digital divide, Europe's Forum on International Cooperation, July 2000

18. Wolfinbager Mary, Gilly Mary - Shopping Online for Freedom, Control and Fun, November 2000

19. Newman Cathy - Silicon Valley Incubator, National Geographic, December 2001

20. James Gleick - Faster, 1999

21. Anders Frank - Spelandets roll i framtiden, September 2000

22. www.idsa.com

23. Gaming Gifts on the Go, Marshal M. Rosenthal, December 2001

24. http://www.igda.org/Endeavors/Research/Online/online.htm 